\title{
Contextualist political theory about multiculturalism in a post-multiculturalist context
}

\author{
Lægaard, Sune
}

Published in:

Ethnicities

DOI:

10.1177/1468796820964304

Publication date:

2021

Document Version

Peer reviewed version

Citation for published version (APA):

Lægaard, S. (2021). Contextualist political theory about multiculturalism in a post-multiculturalist context.

Ethnicities, 21(4), 615-637. https://doi.org/10.1177/1468796820964304

\section{General rights}

Copyright and moral rights for the publications made accessible in the public portal are retained by the authors and/or other copyright owners and it is a condition of accessing publications that users recognise and abide by the legal requirements associated with these rights.

- Users may download and print one copy of any publication from the public portal for the purpose of private study or research.

- You may not further distribute the material or use it for any profit-making activity or commercial gain.

- You may freely distribute the URL identifying the publication in the public portal.

Take down policy

If you believe that this document breaches copyright please contact rucforsk@kb.dk providing details, and we will remove access to the work immediately and investigate your claim. 


\title{
Contextualist political theory about multiculturalism in a post- multiculturalist context
}

Sune Lagaard, Department of Communication and Arts, Roskilde University, Denmark

The official version of this paper has been published in Ethnicities, online first October 2020, DOI:

10.1177/1468796820964304 Link to fulltext: https://journals.sagepub.com/doi/10.1177/1468796820964304

\begin{abstract}
Many theorists of multiculturalism have proposed contextualism as an approach particularly suited for theorizing multiculturalism. The so-called Bristol School of Multiculturalism (BSM) is characterized by a 'bottom up' and claims-based approach eschewing appeal to abstract political principles. Tariq Modood has articulated this contextualist approach as a version of Michael Oakeshott's idea of politics as 'the pursuit of intimations'. The question is how such an approach fares when applied to the specific political and social context characteristic of, especially European, political reality of the last 10-15 years. Political opposition to multiculturalism at ideological and rhetorical levels has characterized this context. At the legal level, many of the laws and rules in place actually protecting minority groups have furthermore not had the form of group rights or policies of recognition proposed by multiculturalist theories. The question therefore arises whether a contextualist approach that takes its point of departure in the facts of such a context can deliver a justification of a recognizable multiculturalist political theory. This is a version of the general problem of critical distance facing contextualism. Modood's version of the approach appeals to the internal diversity of traditions to answer this problem. However, this leads to additional questions about the nature of the theory and the way in which it is action-guiding. Consideration of these questions qualifies the understanding of in which sense the BSM approach is contextual.
\end{abstract}

\section{Keywords}

Action guidance, contextualism, critical distance, methodology, multiculturalism, political theory

\section{Introduction}

Many theorists of multiculturalism (e.g. Will Kymlicka, Joseph Carens, James Tully) have proposed contextualism as an approach particularly suited to theorizing multiculturalism. The so-called Bristol School 
of Multiculturalism (BSM), for instance, proceeds on a 'bottom up' approach, which, rather than deriving policy prescriptions from abstract principles, proceeds from actual claims making from specific groups with a view to achieving real political change (Levey, 2019a). Representatives of the BSM (e.g. Bhikhu Parekh, Tariq Modood) have articulated different versions of this approach. One of their methodological commitments is that political dialogue has to proceed from society's 'operative public values' as a constant frame of reference distinguishing morally acceptable from unacceptable practices. Another is that contextual norms should not be criticized based on abstract principles but through pursuit of Oakeshottian 'intimations' of what changes are possible within the specific political tradition.

The present paper considers this approach in light of the specific political and social context characteristic of European political reality of the last 10-20 years characterized by political opposition to multiculturalism. The question is whether a contextualist approach can justify a recognizable multiculturalist political theory in such a context. This question is a version of a more general worry about contextualist methodologies, namely that they might not be able to provide a sufficiently critical perspective on actual developments. The paper discusses the BSM approach in general, and Modood's articulation of it in particular, in relation to this problem of critical distance, both in order to get a clearer understanding of what the approach consists in and to set out some critical questions that such an approach will have to answer. On the basis of these more general discussions of the sense in which the BSM is contextualist and how it might secure critical distance, the paper suggests that there are different options for how a contextualist defence of multiculturalism might be possible in a post-multicultural context.

The paper first sketches the connection between contextualist approaches and the political theory of multiculturalism. The focus here is on the Bristol School of Multiculturalism, which is precisely characterized by a contextualist approach. The paper then provides a characterization of the European political context of the last 10-20 years which, I argue, can be described as 'post-multiculturalist' in a number of ways. On this basis, I consider how we can understand Modood's invocation of Oakeshott's notion of the pursuit of intimations in relation to the problem of critical distance and the further critical questions to which this gives rise. The concluding section sketches the options for a contextualist defence of multiculturalism in a post-multicultural context.

\section{Contextual approaches to theorizing multiculturalism}

Multiculturalism concerns how states should handle cultural, ethnic and religious diversity. Different societies are diverse in different ways, as a product of different historical developments. Policies for handling diversity inevitably reflect different national models of organisation, decision-making procedures, traditions of administration and political cultures. Therefore, political theorists working on multiculturalism have often 
argued that a political theory of multiculturalism has to take exactly these contextually variable facts into account. This is evident in some of the classic works in political theory on the topic of multiculturalism. Both Charles Taylor's classic essay on multiculturalism and the politics of recognition (1994) and Will Kymlicka's seminal work on minority rights $(1989,1995,2001)$ are clearly responses to the particular Canadian experience with finding a way of recognizing francophone Quebec and indigenous peoples within the mainly Anglophone state. Discussions of multiculturalism in a European context (e.g. Parekh, 2006; Modood, 2007; Laborde, 2008) have rather focused on minorities of mainly immigrant origin, often with a special focus on religious diversity. Precisely because of the contextual differences in the type of diversity addressed and the political context within which it is addressed (e.g. settler states versus old European nation-states, states with or without an imperial past, religiously neutral states versus states with established religion, etc.), the resulting theories of multiculturalism have taken different forms and supported different types of normative claims. While this contextualist approach is characteristic of most works on multiculturalism, some theorists of multiculturalism have gone further and articulated contextualism as a distinctive methodological approach especially suitable for theorizing multiculturalism (e.g. Carens, 2000, for discussion, see Lægaard, 2015).

While the contextualist nature of multiculturalist theories is, at one level, evident and makes obvious sense, as the examples mentioned above testify, it is at the same time often not quite clear what a contextualist approach more precisely consists in, how it differs (if at all) from other approaches or methodologies in political theory, and precisely what difference it makes for the resulting political theories and the normative claims they generate (for discussion of these issues, see Lægaard, 2015, 2016, 2019). In the present paper, I focus on some articulations of what is distinctive about the approach to multiculturalism characteristic of the so-called The Bristol School of Multiculturalism (BSM), identified by Geoff Levey (2019a). The most prominent members of this school are Bhikhu Parekh, Tariq Modood, Nasar Meer and Varun Uberoi. Apart from having worked closely together for many years, these scholars share interests, assumptions and approaches to the study of multiculturalism. For present purposes, there is reason to focus on the BSM both because of the prominence of its individual members in debates about multiculturalism, especially in the British (but also in the broader European) context, and because they, to a significant extent, share approaches and assumptions that qualify as a distinctive contextualist perspective.

It is worth noting here that Levey's identification of the BSM as a 'school' with a specific approach on the one hand has been accepted and largely confirmed by members of the BSM (Meer, 2019; Uberoi and Modood, 2019). On the other hand, Will Kymlicka (2019), whom Levey takes to represent an alternative liberal approach to multiculturalism, has challenged Levey's claim that the BSM is a school with a distinctive approach. Kymlicka takes issue with Levey's claim that the approach he characterizes as distinctive of the BSM really is that. Rather, most theorists of multiculturalism, including Kymlicka himself, 
share this approach and differences that might appear to be indicative of the existence of different schools are really due to differences in the choice of cases (itself a contextualist point). For present purposes, I will not enter this debate. If Levey is right about the distinctiveness of the BSM as a school with its own approach, what I say below only concerns the BSM and others who adopt a similar approach. If, on the other hand, Kymlicka is right, what I say below might be relevant to a broader range of multiculturalism theories.

So what is the distinctive approach of the BSM and in what sense might we think of this as a contextualist approach? According to Levey:

The BSM's first distinguishing feature is that it takes the legitimacy of multiculturalism to derive not from any principle or set of principles, but rather from the situation of flesh and blood people seeking recognition and inclusion in their societies as they are and for what they are. It is a 'bottom-up', sociological, identarian, elementally political and agonistically democratic approach to understanding and justifying multiculturalism. Modood (2001: 248) originally called the approach 'political multiculturalism'. (Levey, 2019a: 205)

Furthermore,

... the Bristol school arrives at multiculturalism by working up from the cultural diversity, identities, difference and consciousness of real life groups rather than 'working down' from a prior commitment to some political values or organizing principle. (Levey, 2019a: 207)

This initial formulation of the approach is not terribly precise. Nevertheless, it does suggest a contrast to a type of multiculturalism theory which takes its point of departure in already established general principles and then in a second step seeks to apply these principles to the particular case of multiculturalism. In some places, this seems to be Levey's understanding of the alternative approach to multiculturalism, which he takes to characterize liberal multiculturalism as a different way of theorizing multiculturalism. By far the most prominent representative of liberal multiculturalism is Kymlicka (1989, 1995, 2001), who did argue about the implication of liberal commitments to equality of opportunity for individuals to claims about minority rights. Levey's formulation suggests that, where liberals like Kymlicka (and Levey himself) start out with established general liberal principles and then only become contextualist in the application of these to specific cases, the BSM does something else.

Kymlicka, however, disagrees with this picture:

According to both Levey and U/M [Uberoi and Modood], the most important distinguishing feature of the BSM is that it adopts a 'bottom-up' focus on actual multicultural claims-making by minority groups, rather than engaging in a top-down application of abstract liberal principles. I agree that this marks an important division amongst theorists, but it does not line 
up with the liberal versus BSM distinction. The reality is that many - if not most - liberal multiculturalists have expressed the same commitment to focusing on real-world claimsmaking. Joseph Carens made this the centre-point of his 'contextual' approach to multiculturalism. (Kymlicka, 2019: 976)

Kymlicka then mentions Alan Patten's work (2014) as an example of the liberal, top-down approach suggested by Levey's formulation. However, he proceeds to mark his own disagreement with such an approach, which he thinks is insufficiently contextualist in the way it poses the initial question that a multiculturalism theory is supposed to answer (this might suggest that Kymlicka's work is a type of 'issue contextualism' as discussed in Lægaard, 2015: 262-263):

In my view, this is a good example of why we need a bottom-up claimsbased approach. Patten's idea of pro-rated spending has no connection to any actual real-world claims - he cites no examples of minorities that have demanded such a policy - in large part because there are no generic states and no generic minorities. What we have instead is a wide range of different state-minority relationships, each intimately tied to different histories of nationbuilding, colonization, immigration, and each generating different types of multiculturalist claims. And so, in my response to Patten, I restated the need for a claims-based approach to theorizing multiculturalism. (Kymlicka, 2019: 976)

Levey has responded to Kymlicka's disagreement with his characterization of the BSM as pursuing a 'bottom-up' approach in contrast to a 'top-down' liberal multiculturalism. Levey acknowledges that, while some liberal theorists (such as Patten) proceed in an abstract fashion, many liberal multiculturalists (such as Kymlicka and Carens) deeply engage with real-life cases and minority claims. However:

Perhaps the language of 'bottom-up' versus 'top-down' did not help here. The contrast I was drawing was not between engagement with actual claims, on the one hand, and theoretical abstraction, on the other. Rather, the contrast has to do with the way in which theorists respond to cases and claims-making. Liberals (among whom I count myself) respond by thinking through the prism of liberal principles and values. We explore the implications of respecting autonomy, of how cultures may be contexts of choice, or the limits of toleration, and so on. That exercise may be conducted abstractly or it may be conducted in close engagement with real-world examples and cases. Either way, the BSM theorists simply do not proceed in the same manner. They feel no need to respond to minority claims through an account of liberalism or liberal values. Instead, their focus is elsewhere: on studying particular minorities and their situation, on intercultural dialogue, on critiquing and remaking the national narrative. (Levey, 2019b: 1003, footnote removed) 
Levey, accordingly, sought to clarify the intended sense of top down/bottom up. He agrees with Kymlicka that the liberal/non-liberal distinction and an abstract/real-world distinction are not co-extensive. In this perspective, whereas Kymlicka pursues a liberal multiculturalism that is often much more real-world and in that sense more contextualist than, for instance, Patten's work, the BSM is both (perhaps even more) focused on real-world cases rather than abstract principles and it does not conceptualize and discuss these cases within a liberal framework.

Until now, the characterization of the approach allegedly characteristic (whether distinctive or not) of the BSM is mainly negative - not abstract and not liberal. Fortunately, there are other suggestions that might help flesh out what positively characterizes the BSM approach. Levey notes that the BSM, following Parekh, also assigns vital importance to 'dialogue' in addressing controversial minority practices, such as female circumcision and polygamy:

This procedure relies heavily on his concept of 'operative public values'. Revealed in a society's constitution, laws and 'norms governing the civic relations between its members', operative public values 'represent the shared moral structure of a society's public life'... The concept underscores the BSM's concern with cultural and political formations in their particularity, and its aversion to abstract and universalising political theory. As others have noted, there are clear echoes here to Oakeshott's ... idea of the 'intimations' of a political tradition. (Levey, 2019a: 208)

Levey furthermore links the notion of operative public values to the BSM's 'ambiguity and ambivalence around liberal values', which he thinks 'would be hard to avoid for the BSM scholars insofar as they recognise operative public values' (Levey, 2019a: 214), which 'are contextually contingent and not universal and hard-wired' (Levey, 2019a: 215). Here are, then, two positive proposals for characterizing the BSM's distinctive methodological approach: it is based on operative public values and it proceeds by way of pursuing 'intimations'. Let us look at each in turn.

As Levey notes, the concept of operative public values was coined by Parekh as part of a discussion of how we should discuss controversial minority practices. Rather than adopting an a priori liberal approach and judge a given practice in terms of whether it is acceptable or not according to abstract liberal principles, controversial practices should be made the object of an intercultural dialogue. This dialogue should furthermore take its point of departure in contextually specific norms and values:

Evaluating minority practices is necessarily contextual in the sense that it occurs within the context of a particular political community whose operative public values provide both its starting point and constant frame of reference. The values help distinguish morally indifferent 
from morally relevant practices and indicate why some of the latter are prima facie unacceptable. (Parekh, 2006: 292)

... there is no single principle in terms of which disputed practices can be evaluated. We start and cannot but start with what I shall call society's operative public values, which provide the context and point of orientation for all such discussions. (Parekh, 2006: 267)

The idea is that minority practices have to be discussed, not in relation to abstract theoretical principles, but within the framework of the norms and values that are actually operative in the society in question.

The other positive suggestion revolves around Oakeshott's notion of 'the pursuit of intimations', which Modood, in several places, mentions as part of his own contextualist approach:

First, Oakeshott contends that political activity necessarily takes place within 'recognized traditions of behaviour' ... Such traditions are, at least for the purposes of the current argument, sufficiently similar to our conception of contexts as complex networks of normative practices. Second, these traditions have several important characteristics: they are 'neither fixed nor finished', they have 'no changeless centre', and no part of them is 'immune from change' ... Third, given these first two aspects of Oakeshott's account, he regards politics as the activity of pursuing and making choices between the intimations or sympathies that we find in these traditions: 'political reasoning', he suggests, involves 'the convincing exposure of a sympathy, present but not yet followed up, and the convincing demonstration that now is the appropriate moment for recognizing it'. (Modood and Thompson, 2018: 353; cf. Modood, 2007: 8)

The first aspect corresponds nicely with Parekh's notion of operative public values. Modood suggests that, because traditions or contexts consist of more than one norm, which may each be interpreted in different ways, contextualist political theorists can offer accounts of what justice requires in a particular situation, which pursue those specific intimations already immanent in the tradition in question. Whereas appeal to general principles that are not arrived at on the basis of an interpretation of an existing tradition amounts to a form of 'ideology' (Uberoi and Modood, 2019: 958), a contextualist political theorist can discuss existing practices and propose changes to them on the basis of the existing tradition because:

... every political context, gives some indication or 'intimation' of what changes are possible, appropriate, necessary and so on. These are matters of judgement, not of rational deductive solutions, but again they point to the importance of understanding the specificity of a context: reformation means a deeper understanding of the specific case and of what is problematic within it. (Modood, 2019: 32) 
Parekh and Modood thus suggest that political theory should take its cue, not from abstract political principles, but from operative public values in the social contexts in question, which theorists should explore by pursuing intimations. One reason for this approach - apart from the fact that they think abstract, top-down political theory is impossible or a form of ideology - is that they want their political theory to speak into the political context and be able to effect real political change. This 'normative sociology or contextualised political theory' seeks to 'direct political theory to real-world, as opposed to abstract, hypothetical problems' and thus 'lends itself to public intellectual engagement' (Modood, 2019: 32). The result is thus not ideal theory but much more 'political' and 'realistic' political theories, which 'identify a concrete problem characteristic of actually existing states and seek normative solutions to that problem that they hope can help to shape real-world decision making and institutional design' (Parvin, 2020: 262).

I hope to have given some idea of in which sense many multiculturalist political theories, and the work of the BSM in particular, can be said to be contextualist. Many of these characterizations are somewhat metaphorical and vague, and they might suggest differences in approaches that are overstated in some respects. But they nevertheless indicate a type of approach and orientation that takes specific contexts to not only be the object and point of departure of political theory, but also takes features of the context to contribute with the evaluative standards on the basis of which political theory can make assessments and offer policy prescriptions. In the next section, I will consider some aspects of what I take to be the current European political context with a focus on multiculturalism.

\section{Multiculturalist theorizing in a post-multiculturalism context}

Some theories of multiculturalism were formulated as a response to actual state policies with an aim to providing rationales and justifications for these policies. This is arguably the case for Taylor and Kymlicka's theories, which largely are attempts at showing how Canadian policies concerning Quebec and indigenous peoples are consistent with liberal democracy. Much of the work of the BSM has rather emerged as a critical response to events such as the Rushdie Affair. However, to some extent the BSM approach to multiculturalism is also an attempt to articulate and support a distinctive British approach to cultural diversity.

Whereas theorists of multiculturalism working in the 1990s could say with some confidence that they were theorizing an existing set of policies, which could be argued to point in the direction of a more accommodating multicultural society, this has arguably changed. As Phil Parvin (2020) notes, there are several different stories about exactly when things changed and due to which factors. Whether one points to the 9-11 attacks and subsequent Islamist terrorism and securitization, to the financial crisis, or to the refugee crisis, it seems clear that the present context is not one where multiculturalism enjoys either social or 
political support. As pointed out by many scholars (for a seminal collection on this, see Vertovec and Wessendorf, 2010), there has been what is often called a 'multiculturalism backlash'. There is disagreement about the extent of this backlash. Most theorists agree, however, that many prominent political actors have denounced multiculturalism, at least at the level of rhetoric. Whereas countries like the Netherlands and Sweden officially labelled themselves multiculturalist in the 1990s, European political leaders have subsequently joined each other in proclaiming the failure of multiculturalism (Chin, 2017).

As Kymlicka (2010: 97) noted, although people disagree about what comes after multiculturalism, 'there is a surprising consensus that we are indeed in a post-multicultural era'. It is quite complicated to say what the alleged death of multiculturalism involves, apart from a change at the level of political rhetoric, since there never was an official multiculturalism policy in most European countries and few actual multiculturalism policies amounting to the kind of minority rights on which Kymlicka's theory focuses (Joppke, 2017). One prominent development is that most Western states have adopted stricter civic integrationist regimes, which place emphasis on demands for acceptance of liberal values and even assimilation on immigrants. There is relatively little public recognition or accommodation of cultural differences.

Even though there are disagreements about the extent of the failure of or backlash against multiculturalism, it is undoubtedly a feature of the present social and political context. This is the case at several levels and in several respects, which together might be taken to provide a characterization of some of the main ways in which the current European context can be described as post-multiculturalist:

At the policy level, there are very few actual multiculturalism policies in place in Europe, at least if one focuses on policies regarding minorities of immigrant background rather than national minorities or indigenous peoples, and especially if one adopts an understanding of multiculturalism policies as either acts of official recognition or as the granting of minority rights. To the extent that something along these lines is the criterion of multiculturalism, it is close to non-existent in most European countries. This accordingly means that a multiculturalist theory in a European context cannot claim to be providing a rationale or justification for existing policies in the manner in which Kymlicka's theory could do regarding Canadian policies in the 1990s.

More general laws, such as the European Convention of Human Rights or anti-discrimination law in all EU countries as implementation of EU directives, which are of great practical importance for members of minorities, are characterized by a strong individualist approach. These laws protect individuals largely irrespective of whether they belong to minority groups, rather than extending status to minority groups as such. They seem to be elements of a strongly liberal approach rather than a distinctive form of multiculturalism, at least insofar as one focuses on a type of multiculturalism that is not based on liberal premises, as the BSM according to Levey supposedly does. 
At the level of political rhetoric, it is evident that multiculturalism has been denounced by most political actors across most European countries - curiously enough also in many countries where there was never anything even remotely resembling an official multiculturalism policy in place. Therefore, a multiculturalist theory in a European context cannot claim to provide ideological backing to such official policies.

At the level of public support, the picture is naturally much less clear. It is furthermore a good question: what would count as a reliable measure for support for multiculturalism? One clear tendency, however, is that electoral support for restrictive immigration policies has increased during the last two decades in most European countries. This is both the case for more or less far right parties with explicitly nationalist and even xenophobic agendas and for more centrist parties which have taken over elements of the restrictive policies previously reserved for far-right parties in order to stem or reverse the flow of voters towards these parties. In principle, immigration policy and multiculturalism are two analytically different things. There is nevertheless a connection, both at the level of public sentiments (people critical of immigration are often also critical of multiculturalism, and vice-versa, both in the descriptive sense of cultural diversity and in the normative sense of policies aimed at recognizing and accommodating such diversity) and political argument (criticism of immigration and of multiculturalism are often blurred, cf. Lægaard, 2017). So a multiculturalist theory in a European context arguably cannot claim to articulate claims with strong support in the electorate.

Given the characterization of contextualism in the previous section, the question arises whether a contextualist approach under such post-(or even anti-)multiculturalist circumstances can justify a recognizably multiculturalist theory. This is a pressing question, especially for theories like those of the BSM, which seek to both criticise and offer alternatives to existing political arrangements that do not recognize or treat minority groups in an equitable manner and, at the same time, insist on basing such criticism and advocacy on contextualist grounds.

To put it very roughly, one might characterize the BSM (and theorists with similar approaches) as having both a normative and a methodological commitment. The normative commitment is to advocacy of multiculturalism policies in a broad sense (i.e. not only minority rights in Kymlicka's sense, for instance, but policies that accommodate minorities more broadly), coupled with criticism of existing arrangements that do not adequately recognize and accommodate minority groups. The methodological commitment is to a contextualist approach to formulating and justifying these normative claims, as characterized in the previous section. The question is whether the methodological commitment, which requires the theorist to argue from operative public values and by way of the pursuit of intimations in the existing political tradition, can justify the kind of multiculturalist normative claims required by the normative commitment under conditions of post-multiculturalism as sketched above.

Levey articulates this worry when he writes that, exactly because of the importance of culture articulated by the BSM, 'it might be reason for many longstanding citizens to want to restrict entry to those who are 
culturally similar. Many Brexiteers seem to have arrived at such a conclusion. In that case, multicultural policy would mainly operate at the borders through immigration policy' (Levey, 2019a: 220). He further remarks that:

The Bristol school scholars are well aware of the risk of a backlash ... having also had a taste of it in the fallout from the Parekh Report ... Where they 'ask for more' it is invariably in the most civil and reasoned way. The BSM oscillates politically as well as philosophically in that tense area between radical critique and provisional acceptance. (Levey, 2019a: 220)

One way of reading these comments is as saying that, precisely because of the contextualist approach required by the methodological commitments of the BSM, the extent to which BSM scholars can criticize existing arrangements is limited, and they might be forced to accept some arrangements even though they do not deliver the desired kind of multicultural recognition and accommodation.

Uberoi and Modood also seem to acknowledge this danger, when they write that:

... if most British people have conceptions of Britain that exclude cultural minorities, then they will think of such minorities as outsiders. This can exacerbate the exclusion and discrimination that cultural minorities often experience and make such minorities unwilling to be part of a group that mistreats them. (Uberoi and Modood, 2019: 962)

One might sum these worries up by relating them to the different aspects of the contextualist approach sketched by Levey and members of the BSM. One aspect concerns the methodological commitment to starting out from operative public values. Here, the worry takes the form that perhaps the actually operative public values in European countries are not susceptible to a multiculturalist interpretation, and perhaps they might even rather push a political theory that has to take them as a guiding framework in the direction of other types of policies, e.g. liberal individualist forms of non-discrimination or even civic integrationist policies.

Another aspect of the BSM's contextualist approach concerns the ambition to provide a political multiculturalism that speaks to actual political actors and has the potential for effecting real political change. For such an ambition to hold, the content of the proposed policies will have to appeal to both political actors and indirectly to the electorate that is to put or keep these actors in office. Given an immigrant-hostile electorate, the upshot of such a political multiculturalism is likely to be much less multiculturalist than one would otherwise have expected or perhaps hoped for.

This, then, is the worry facing contextualist forms of multiculturalism operating in a post-multiculturalist context. The question now is how seriously we should take this worry. 


\section{Critical distance in contextualism}

A contextualist approach, on the one hand, leads to worries such as the one sketched in the previous section as to whether the methodological commitment to contextualism under conditions of post-multiculturalism can justify the kind of multiculturalism to which the BSM is normatively committed. Modood has himself articulated this worry as 'the problem of critical distance' (Modood and Thompson, 2018, cf. Carens 2013: 299). On the other hand, a contextualist methodology of course does not commit one to simply accepting the policies, rhetoric or attitudes actually existing in a given context. Modood and Thompson explicitly state that 'our sort of contextualist also seeks to achieve critical distance from the norms which characterize the contexts with which she is concerned' (Modood and Thompson, 2018: 350). Critical distance would mean that a contextualist approach might still justify a normative commitment to multiculturalism, even if the context were post-multicultural in the sense discussed in the previous section.

However, there are (at least) two structurally different ways in which one can try to achieve this kind of critical distance within a contextualist approach. One way is to look at several contexts together, so that each context (for instance, a national jurisdiction) provides a degree of critical distance to other contexts. Another way is to look for inconsistencies and possibilities for alternative interpretations of existing norms within a given context. Modood and Thompson advocate the first recipe for achieving critical distance in their proposal for what they call an 'iterative contextualism', according to which:

... what justice requires in each particular context is never a simple and direct function of the norms to be found there. Although principles are generated by a process of reflection on context, because this process is iterated across a number of such contexts, the principle which emerges will be at variance with the set of norms which characterize any one of them.

(Modood and Thompson, 2018: 350)

Modood suggests the other way of seeking critical distance in his already mentioned invocation of Oakeshott's idea of the pursuit of intimations, which restricts itself to a single context understood as a tradition. According to this idea, a theorist can pursue intimations already present in a tradition, which indicate what changes are possible, appropriate or necessary (Modood, 2019: 32). Critical distance is thus established between how the tradition is presently understood and practiced, e.g. in the form of institutions and laws, and how it could be understood, which would involve a shift in practice, laws or institutions. The two potential pathways to critical distance are, in principle, compatible, so adopting one does not necessarily bar one from also making use of the other. They are nevertheless structurally different, so it makes sense to discuss them separately. Furthermore, some might think that the second approach is more genuinely contextualist than the first approach, since the first, iterative approach allows itself a crosscontextual perspective and thus involves criticism of norms holding in a local context based on principles 
justified by way of appeal to other contexts. This can raise worries that iterative contextualism still imposes external standards that do not take proper account of the particularities of a given context (Hills, 2020). Iterative contextualism is at least a version of the strategy of 'widening' the context, e.g. to include several distinct national jurisdictions as a basis for discussing a specific type of law, as a way of securing critical distance (Lægaard, 2016: 17-18). The more one widens the context by allowing appeal to principles based on, e.g., other national jurisdictions, the more likely it becomes that one can find a principle that will justify criticism of a given local norm, practice, institution or law. At the same time, the wider one goes in search for principles that will provide critical distance, the less distinctively contextualist the approach and the resulting theory and normative judgments will be.

While iterative contextualism does provide a solution to the problem of critical distance, it simultaneously gives rise to other questions that have to be answered, as I have argued elsewhere (Lægaard, 2019). For this reason, and because some contextualists might think that iterative contextualism is not a genuine sort of contextualism, I will here focus on the other narrower approach.

As described above, Modood appeals to Oakeshott's idea that politics necessarily takes place within 'recognized traditions of behavior' (Oakeshott, 1962: 123), which are 'neither fixed nor finished', have 'no changeless centre', and no part of which is 'immune from change' (Oakeshott, 1962: 128). This part of the Oakeshottian picture is mainly a claim about how actually existing political behavior looks when viewed as a tradition: it is continuously developing and complex in ways where one cannot say that one idea or principle is most fundamental or has priority. This is probably a true claim about how politics actually works. It is certainly not the case that there always is one principle or value that trumps all other considerations, and it is furthermore undeniable that the relative weight of different values changes over time, as well as the understanding about what a given value means or involves.

Why is this characterization of political traditions important (apart from the fact that it is probably true)? Because the more complex and dynamic traditions are, the less danger there seems to be that the noted contextualist methodological commitment leads to a lack of critical distance in the form of a problematic form of conservatism or status quo bias. Given this characterization of traditions, most traditions (at least the ones still alive and well) will have sufficient internal diversity and resources for criticism of the present acts performed in the name of the tradition or the established ways of carrying out the tradition in practice.

The question then is how political theory at a more practical level is supposed to make use of this internal diversity of traditions. It is one thing to say that traditions are, in fact, dynamic and complex. It is quite another to provide an account of how political theory should proceed when discussing cases within a given tradition, especially if one also has a normative commitment to criticizing features of the tradition or advocating for multiculturalism policies, which require reform of the status quo, as is the case for the BSM. 
Modood's answer is that political theory should adopt Oakeshott's idea of:

... politics as the activity of pursuing and making choices between the intimations or sympathies that we find in these traditions: 'political reasoning', he [Oakeshott] suggests, involves 'the convincing exposure of a sympathy, present but not yet followed up, and the convincing demonstration that now is the appropriate moment for recognizing it'. (Modood and Thompson, 2018: 353)

Whereas iterative contextualism was a version of the strategy of 'widening' contextualism, the pursuit of intimations seems a version of the strategy of 'deepening' contextualism (Lægaard, 2016: 18-19). This approach requires deeper and more fine-grained understanding of the context in question in order for the theorist to identify possibilities for novel interpretations and new developments of a tradition.

One immediate response to the invocation of the idea of pursuit of intimations might be that, whereas Oakeshott provided an account of the activity of politics, the present question concerns something different, although related, namely the activity of political theory. Oakeshott offered a descriptive and explanatory account of how actual politics works (when it works), i.e. that successful advocacy of policies and reforms depends on politicians being able to present their case for these as being in tune with the political tradition within which the case has to be made. This might be a correct account of politics and still be beside the point as an account of how to do political theory aimed at justifying normative claims. Something similar can be said regarding Parekh's parallel proposal for political dialogue within the framework of a society's operative public values as the appropriate approach to multicultural controversies. This might be a correct and reasonable characterization of how political debate on such issues in fact works - and has to work - but this does not in itself show that it is also an appropriate account of how political theory of multiculturalism should proceed (Lægaard, 2015: 267-268).

This objection to Modood's invocation of Oakeshott's notion of intimations relies on a difference between politics and political theory. It is, in itself, a controversial question whether there is such a distinction and, if so, how we should understand it. However, even though Modood invokes Oakeshott as a source of the idea of pursuit of intimations, Oakeshott himself apparently did not think of this as a methodology for political theory (Orsi, 2015). Oakeshott offered the idea of the pursuit of intimations as a description of political reasoning, which he argued was necessarily dialectical, circumstantial, conditional and contingent in the sense that it had to appeal to shared assumptions. However, he explicitly distinguished between this description of how political reasoning had to work and the level of political philosophy, which he thought was not normative. Oakeshott thought that discussion of first-order normative claims was not philosophical and that philosophy was rather a second-order reflection on modes of experience. Therefore, Modood is either extracting the idea of the pursuit of intimations from its original context and using it in a different 
sense than Oakeshott himself did, or he is relegating his own work to the level of politics rather than political philosophy.

This latter possibility suggests another possible interpretation of Modood's contextualist approach. ${ }^{1}$ Already in Levey's initially quoted characterization of the BSM, as well as in Modood's own work, Modood's work is described as 'political' multiculturalism (Modood, 2007: 7, 18-19; Levey, 2019a: 205, cf. also Parvin, 2020: 253,262). Modood (2019: 220) explains this by invoking a contrast to the multiculturalisms of Charles Taylor and Bhikhu Parekh, who both base their political discussions of multiculturalism on what Modood terms a broader 'philosophical multiculturalism'. In contrast, Modood's multiculturalism is supposed to be political in the sense that it is not based on philosophical ideas, e.g. about human nature or fundamental needs for recognition. When he writes about recognition, for instance, this is not as an implication of some philosophical anthropology, but as a way of capturing and addressing actual political claims for recognition from specific minority groups. So 'political' here both means something akin to what Rawls (1996) means by it, i.e. that Modood's multiculturalism abstains from invoking more fundamental metaphysical assumptions. However, and in contrast to Rawlsian political liberalism focused on abstract and ideal principles, it also means that the theory proceeds from and concerns itself with actual political claims.

Modood thus does not intend his theory to be strictly separated from the practice of politics. The theory is supposed to capture the issues and debates that actually occur within politics and it aims to feed ideas and proposals back into politics, on which political actors can act. On this basis, one might think that Modood deliberatively adopts what Oakeshott originally proposed as an account of the practice of politics as a methodological description of his theoretical approach. One way to understand this would then be that Modood's approach is a species of so-called political realism within political philosophy. According to political realism, political philosophy should not proceed as applied moral philosophy (what realists call 'moralism' or the 'ethics first' approach). Some political realists go as far as rejecting the idea of prescriptive political theory in order to redirect political theory towards theoretical understanding of politics rather than normative prescription (Horton, 2017). However, Modood's multiculturalism is clearly not realist in this sense; if he is a political realist, he is still squarely within the prescriptive camp concerned with offering normative criticism and policy proposals. Prescriptive political realists still want to do normative political theory, but they want their principles and prescriptions to be of a distinctive political nature, not only in terms of what they concern and are applied to, but also in terms of the sources and justifications for them and the type of normativity involved (Rossi and Sleat, 2014).

We might accordingly understand Modood's appeal to Oakeshott's notion of the pursuit of intimations as a version of political realism. Here, this would then mean a) that it is not based on a philosophical multiculturalism, b) that it is claims based (rather than derived from abstract principles), and c) that the kind of normativity involved in the criticisms offered and in the policy prescriptions is itself political. This last 
claim, in turn, means that the normative force depends on values already operative in the tradition in question, which the theorist engages by pursuing intimations.

\section{Action guidance in contextualism}

While the political realism reading of Modood's invocation of Oakeshott's idea of the pursuit of intimations provides an explanation for why Modood appeals to an account originally offered as a description of the practice of politics in a discussion of the methodology of political theory, it still leaves questions unanswered. One is what the pursuit of intimations more precisely consists in as a method; what are political theorists expected to do that will justify their normative judgments? We still need to know how this approach ensures the kind of critical distance required to justify something resembling a multiculturalist theory in a post-multiculturalist context.

To address these questions it is worth comparing pursuit of intimations with another type of narrow contextualism that focuses on a specific context (rather than on comparing contexts, as Modood's iterative contextualism does), namely what is often called immanent critique or internal criticism (Lægaard, 2016: 16-17). Roughly, this approach looks for inconsistencies within a given context in order to apply the rationales and justifications given within the context to practices within the context, thereby showing that practices fail according to the supposed rationales or justifications for them. Modood's idea of pursuit of intimations seems different from internal criticism in the sense that he describes intimations as indications of what changes are possible, appropriate and necessary. An intimation accordingly seems to point to positive proposals for action. Pursuing an intimation thus seems different from conducting internal criticism, since the former is about choosing one course of action over others, whereas the latter is about exposing inconsistencies between actions and proposed rationales.

There are limits to internal criticism as a methodology for political theory. If a norm and a practice do not cohere, we can rectify this contradiction either by changing the norm or by changing the practice. Identification of the contradiction does not in itself tell us which of these ways forward to prefer (Lægaard, 2016: 17). So internal criticism is not action guiding. The point of pursing intimations precisely seems to be that Modood intends this to be action guiding. The question is how the theorist can arrive at judgments about which changes are 'appropriate', as Modood puts it.

If politics is the pursuit of intimations, the question is how we can choose between conflicting intimations within a given tradition. Oakeshott's idea of pursuit of intimations was precisely criticised on the grounds that it lacked a criterion of choice between different practical options (Orsi, 2015: 552). In other words, the pursuit of intimation is not action guiding either - or, rather, it provides no rational grounds for pursuing one choice rather than another. Recently, Peter Hills (2020) has reasserted a similar criticism against Modood's 
use of the pursuit of intimations. According to Hills, even if contextual origin is taken to be a necessary criterion for a valid principle, as must be the case according to contextualism, it cannot be sufficient whenever there are two or more conflicting normative arguments, which share that origin. If there are intimations pointing in different directions within a given tradition, which is what ensures that a contextualist approach focusing on pursuit of intimations can retain critical distance, then appeal to the fact that a given course of action is intimated fails as a reason for choosing it over an alternative course of action that is also intimated. The internal diversity of traditions that explains why pursuit of intimations can answer the problem of critical distance at the same time raises the worry that pursuit of intimations fails to be action guiding (this is analogous to the trilemma for internal criticism described in Lægaard, 2016: 17). In order to get action guidance, substantial argument about the comparative merits of the conflicting intimations is required, for example, that one course of action fits better with other commitments present in the context. Then it is not the mere fact that a value is contextual that is doing the argumentative work but rather the theorist's substantive argument about it and its coherence with other commitments. ${ }^{2}$

One possible answer to this problem of action guidance, which furthermore fits well with the previously mentioned 'political' and 'realistic' reading of Modood's invocation of the pursuit of intimations, is that the multicultural theorist is supposed to be guided by the interests and concerns of the minority groups whose claims making provides the point of departure. This picture fits with one aspect of Modood's characterization of his own work as a form of 'public intellectual engagement', which is necessarily committed to specific groups and causes (2019: 222). From this point of view, that the BSM is doing 'bottom up' political theory not only means that it takes its point of departure in political claims articulated in actual political debates, but also that it takes the side of certain political actors in these debates.

To take an example from Modood's own work, there is tension between avowed principles of secularism, which are often interpreted as requiring separation of politics and religion, and the actual existence of established churches, e.g. the Anglican Church in England. This tension can either be resolved by disestablishment (what Modood calls 'radical secularism') or by reinterpreting secularism as what Modood calls 'moderate secularism', which allows state recognition of religion. In principle, one could go either way. However, because Modood approaches this issue from the point of view of Muslim minorities in Britain, who - according to Modood - are not interested in disestablishment, since they prefer to live in a state that recognizes the public value of religion, moderate secularism is the right way to go here (Modood, 2007, 2019, see Lægaard, 2015, for discussion of Modood's argument).

This 'political' approach provides an answer to the problem of action guidance, as well as to how the pursuit of intimations relates to the claims based approach of the BSM. Since the BSM, according to this understanding, is from the outset on the side of specific minority groups and therefore oriented towards providing support for political claims advanced by them, pursuit of intimations means looking for the 
intimations that best provide this support. If there are different possible courses of action intimated by a given tradition, the way out is to choose the one that best supports the claims of the minority group.

There are two problems with this response to the problem of action guidance. First, this answer opens up the theory to charges of sectarianism. This way of understanding multiculturalist political theory turns it into a type of political activism, which is concerned with articulating rationales supporting the partisan claims advanced by specific minority groups. The problem is not that there is anything wrong in supporting the claims of minority groups. The problem is rather that political theory is supposed to offer reasons that appeal irrespective of partisan commitments. So if multiculturalism is really just minority activism, why should people who do not share the view listen?

A second problem is that taking a partisan/engaged position only solves the problem of action guidance if the minority group in question has one single view or one coherent set of concerns. However, this is rarely the case. Minority groups are internally diverse, just as the entire society and different sub-groups within a minority are likely to have different views and priorities. Therefore, if multicultural theory is guided by what provides support for minority claims, the theorist will often have to choose among divergent claims from within the same minority group. Muslims are for instance unlikely to have one view, they are likely to disagree internally based on whether they are secular or religious, homosexual or heterosexual, conservative or liberal, etc. Modood seems aware of this danger, since he warns against public intellectual engagement becoming 'one-sided' and notes how multiculturalists are likely to belong to more than one group and therefore are unlikely to be either wholly insiders or outsiders (2019: 223).

\section{Conclusion}

The BSM is characterized by a contextualist approach, of which Modood's appropriation of Oakeshott's idea of politics as the pursuit of intimations is one version. One question facing such a contextualist approach is how a methodological commitment to contextualism is compatible with a normative commitment to multiculturalism if the context becomes post-multicultural. Modood's characterization of a tradition as internally diverse, as well as the interpretation of the BSM as a form of political realism, provides a general answer to this version of the problem of critical distance; if a tradition is internally diverse, pursuit of intimations does not necessarily lead to a problematic form of conservatism. The question motivating the present paper is more specific, however, namely what a contextual approach to multiculturalism can say when the context becomes post-multicultural. Can one still provide a contextual defense of multiculturalism in 2020 ? If so, how would a contextual defense of multiculturalism in 2020 be different from a contextual defense of multiculturalism in, say, 1990? If there is no difference, despite the change in the political context, in what sense is the defense contextual $?^{3}$ In this concluding section, I return to the original question and 
consider the implications of the discussion of the contextualism of the BSM for the defense of multiculturalism in a post-multicultural era.

I noted a structural difference between two ways in which Modood appeals to context. Iterative contextualism works by comparing different contexts whereas the pursuit of intimations stays internal to one context understood as a tradition. While the focus has been on the latter, it is worth noting that the former type of iterative contextualism would address the fact of post-multiculturalism precisely by comparing and contrasting different contexts (e.g. national jurisdictions). It might ask how values that go through a postmulticulturalist transformation in some contexts (e.g. civic integrationism in continental Europe) are differently inflected in other contexts (e.g. more accommodationist interpretations in the UK or Canada). Iterative contextualism would thus be able to criticize post-multiculturalism in one context based on different interpretations of similar values in other contexts.

Such a cross-contextual approach is not what characterizes the pursuit of intimations, so criticism of, or distance to, post-multiculturalism needs another basis here. Within such an approach, there seem to be three basic options: ${ }^{4}$

1. The fact that we live in a post-multicultural context means that we can no longer defend multiculturalism;

2. We can still defend multiculturalism in a post-multicultural context, but the arguments required would need to be different from, say, those in the 1990s, given the changes in political context;

3. The political changes in context, e.g. between 1990 and 2020, make no difference to how we defend multiculturalism: the sort of context that matters for political theory operates at a completely different level than these surface changes in political culture or political rhetoric.

One way of understanding the difference between these three options is by the implied view of the operative public values in the context, which are related to what Modood talks about as a tradition. According to the first two options, the changes in context also involve changes in the operative public values or in the tradition. The operative public values in the UK are simply different now than, say, in the 1990s.

According to the third option, however, the relevant context is determined by deeper and longer-term historical processes or institutional structures. This means that Britain in 2020 is, for the purpose of political theory, the same context (has the same operative public values) as Britain in 1990. Therefore, the same contextual arguments apply, regardless of recent trends in public opinion or public policy. This third answer effectively says that, appearances notwithstanding, we do not really live in a post-multicultural context after all. Alternatively, or perhaps more precisely, while we certainly do live in a post-multicultural context with respect to political rhetoric and popular sentiments, these aspects of the context are not what matter for the identification of the operative public values and the tradition in the relevant sense. 
Such a view can come in different degrees. According to one moderate version, operative public values are not defined or captured by opinion polls, politician declarations, or similar momentary data; they are defined by the constitution, laws, institutions and governing norms of a society. This view thus allows that there can be widespread political and popular hostility to multiculturalism at a given time, but the operative public values can still favor multiculturalism. The crucial question is how 'deep' one needs to go to identify the operative public values. If the relevant level includes the present laws of the land, then legislative changes may be non-conducive to the kind of multiculturalism advanced by the BSM, and this would thus a more serious challenge for its contextualism. To avoid this, a more radical version of the view would hold that the relevant level is much deeper. The operative public values could thus be unaffected, not only by shifts in rhetoric and popular sentiment, but by changes at the legislative level as well.

The more radical view one takes in this respect, the more potential there is for maintaining an argument for multiculturalism based on operative public values despite the increasing post-multicultural nature of the context. This would make the methodological commitment to contextualism compatible with the normative commitment to multiculturalism.

This response raises a curious challenge for contextualist multiculturalism. If contextualism means basing normative arguments on operative public values drawn from pursuit of intimations in the context, but the relevant aspects of the context are so deep that they are unaffected by most of what ordinary actors in the context think and do, in what sense is this still contextualism? Furthermore, this radical view of the deepness of operative public values does not square well with the concern of the BSM with actual political claims. If the multiculturalism defended by the BSM is claims based, it seems strange to hold that what goes on at the everyday level of politics where these claims are articulated is not relevant for the operative public values in relation to which the claims should be justified. Therefore, this radical move does not provide a promising way of grounding the contextual defense of multiculturalism for adherents of the BSM.

The second option above seems more plausible, namely to hold that the context has, indeed, changed but that this does not preclude a defense of multiculturalism, although the specific arguments have to reflect the change in context. In fact, much of the recent work by representatives of the BSM seems to provide possible examples of this, e.g. the engagement with interculturalism as an alternative way of handling diversity (Meer et al., 2016). Support for interculturalism is one aspect of the post-multicultural context and the specific engagement with this alternative approach is thus an example of the second option above. Something similar is arguably the case for the engagement with nationalist populism (Modood, 2020), which is also an aspect of the post-multicultural context and used by the BSM as a springboard for defending its version of multiculturalism in this new context. To which extent these two examples are surface changes in rhetoric or deeper changes in operative public values, and whether the particular arguments of the BSM against interculturalism and for a multicultural nationalism do indeed manage to justify multiculturalism based on 
operative public values present in the post-multicultural context is a further question that goes beyond the present paper. However, I hope to have shown that it is crucial to assess whether contextual arguments for multiculturalism succeed in a post-multiculturalism context and that there might be ways of understanding the contextualism of the BSM that do not preclude this.

\section{References}

Carens JH (2000) Culture, Citizenship, and Community: A Contextual Exploration of Justice as Evenhandedness. Oxford: Oxford University Press.

Carens JH (2013) The Ethics of Immigration. Oxford: Oxford University Press.

Chin R (2017) The Crisis of Multiculturalism in Europe: A History. Princeton: Princeton University Press. Hills PM (2020) Conflicts and Reasons in Contextual Normative Theory: A Reply to Modood and Thompson. Res Publica, published online 20 April 2020, DOI: 10.1007/s11158-020-09460-6

Horton J (2017) What Might it Mean for Political Theory to Be More 'Realistic'? Philosophia 45: 487-501. Joppke C (2017) Is Multiculturalism Dead? Cambridge: Polity.

Kymlicka W (1989) Liberalism, Community and Culture. Oxford: Oxford University Press.

Kymlicka W (1995) Multicultural Citizenship. Oxford: Oxford University Press.

Kymlicka W (2001) Politics in the Vernacular. Oxford: Oxford University Press.

Kymlicka W (2010) The Rise and Fall of Multiculturalism? New Debates on Inclusion and Accommodation in Diverse Societies, International Social Science Journal 99: 97-112.

Kymlicka W (2019) Deschooling multiculturalism. Ethnicities 19(6): 971-982.

Laborde C (2008) Critical Republicanism. Oxford: Oxford University Press.

Levey GB (2019a) The Bristol school of multiculturalism. Ethnicities 19(1): 200-226.

Levey GB (2019b) Differentiating multiculturalisms: A rejoinder. Ethnicities 19(6): 999-1014.

Lægaard S (2015) Multiculturalism and contextualism: How is context relevant for political theory?

European Journal of Political Theory 14(3): 259-276.

Lægaard S (2016) Contextualism in Normative Political Theory. In: Thompson W. R (ed.) Oxford Research Encyclopedia of Politics. Oxford: Oxford University Press. 
Lægaard S (2017) On the Reciprocal Subordination of Multiculturalism and Migration Policies. In:

Triandafyllidou A (ed.) Multicultural Governance in a Mobile World. Edinburgh: Edinburgh University

Press, pp. 245-264.

Lægaard S (2019) Contextualism in normative political theory and the problem of critical distance. Ethical Theory and Moral Practice 22(4): 953-970.

Meer N, Modood T and Zapata-Barrero R (2016) Multiculturalism and Interculturalism. Edinburgh:

Edinburgh University Press.

Meer N (2019) The Bristol School of Multiculturalism, and the political sociology of identity. Ethnicities 19(6): 991-998.

Modood T (2007) Multiculturalism: A Civic Idea. Cambridge: Polity.

Modood T (2019) Essays on Secularism and Multiculturalism. London: Rowman \& Littlefield.

Modood T (2020) Multiculturalism as a New Form of Nationalism? Nations and Nationalism 26: 308-313.

Modood T and Thompson S (2018) Revisiting Contextualism in Political Theory: Putting Principles into Context. Res Publica 24: 339-357.

Oakeshott M (1962) Rationalism in Politics and Other Essays. London: Methuen.

Orsi D (2015) Oakeshott on Practice, Normative Thought and Political Philosophy. British Journal for the History of Philosophy 23(3): 545-568.

Parekh B (2006) Rethinking Multiculturalism, second edition. Basingstoke: Palgrave.

Parvin P (2020) Diversity in an Anti-Immigration Era: Theories, Controversies, Principles. Ethnicities 20(2): 251-264.

Patten A (2014) Equal Recognition: The Moral Foundations of Minority Rights. Princeton: Princeton University Press.

Rawls J (1996) Political Liberalism. New York: Columbia University Press.

Rossi E and Sleat M (2014) Realism in normative political theory. Philosophy Compass 9: 689-701.

Taylor C (1994) The politics of recognition. In: Gutmann A (ed.) Multiculturalism and 'the Politics of Recognition'. Princeton: Princeton University Press, pp. 25-73.

Uberoi V and Modood T (2019) The emergence of the Bristol School of Multiculturalism. Ethnicities 19(6): 955-970. 
Vertovec S and Wessendorf S (eds) (2010) The Multiculturalism Backlash: European Discourses, Policies and Practices. London: Routledge.

\footnotetext{
${ }^{1}$ I owe this suggestion to Tariq Modood.

${ }^{2}$ Thanks to a reviewer for pressing the point that that the internal diversity and conflicting commitments of contexts does not imply that contextualism has no contextual basis for preferring one rival commitment, value, or practice over another. My point is that, while the basis is contextual, the choice about which of the ways intimated in the context to go requires more than appeal to this fact. Any assertion of a value as being integral to a tradition of course involves an interpretation, so I do not hereby commit myself to any view about whether values exist independently of interpretation. I merely claim that interpretation of a tradition can, and often will, yield conflicting intimations (anything else would be strange in light of pluralism). Therefore, a claim that a course of action is supported by intimations in the context involves both a claim that there are values in the context supporting it and a further substantive claim that the balance of these values favors one rather than another course of action. The latter seems to require substantial argument that goes beyond the mere claim that certain values are intimated in the context.

${ }^{3}$ Thanks to an anonymous reviewer for this more pointed way of posing the question of the paper.

${ }^{4}$ I also owe this way of framing the options as well as suggestions about some of the options to two anonymous reviewers.
} 